${ }^{\circ}$ Entomologica Fennica. 5 December 1995

\title{
Plecopteran communities and annual emergence in five forest streams and two lake outlet streams of central Finland
}

\author{
Pauli Bagge \& Juhani Hynynen
}

Bagge, P. \& Hynynen, J. 1995: Plecopteran communities and annual emergence in five forest streams and two lake outlet streams of central Finland. Entomol. Fennica 6:99-108.

The plecopteran fauna was studied by means of slit traps and hand net during the summers of 1982-1987. A total of 19 plecopteran species comprising c. 4500 adults and c. 2900 larvae were sampled in streams. Of these, Capnia atra, Capnopsis schilleri, Nemurella pictetii and Isoperla difformis were recorded for the first time in the streams of the province Pohjois-Häme $(T b)$. The plecopteran fauna was richest in the small forest streams and relatively poor in the largest outlet. Both, the character of the stream bed and the quantity and quality of food available seemed to be the most important factors affecting the occurrence of the plecopteran species. In the brooks the emergence of stoneflies had two clear maxima: one in spring and another in late autumn. Vernal species were Taeniopteryx nebulosa, Isoperla difformis, Nemoura avicularis, $N$. flexuosa and Leuctra hippopus. Dominant species in the autumnal cathes were Leuctra fusca and Leuctra digitata. In the outlet streams the succession of emergence was somewhat different owing to the weak emergence and due to the cold summer with strong floods in 1987. The slit trap method worked well in the catching of stoneflies except during the snow melting seasons and the flood periods.

Pauli Bagge, Dept. of Bio- and Environmental Sciences, University of Jyväskylä, P.O. Box 35, FIN-40351 Jyväskylä, Finland

Juhani Hynynen, Institute for Environmental Research, University of Jyväskylä, P.O. Box 35, FIN-40351 Jyväskylä, Finland

\section{Introduction}

Temperature, discharge and the spatial environmental heterogeneity are important factors affecting the species diversity of aquatic insects in streams (Stanford \& Ward 1983, etc.). The effects of temperature and flow conditions on the occurrence of stoneflies in the Scandinavian streams were already discussed by Brinck (1952) and in more detail by Lillehammer (1975). Other factors influencing the abundance and spatial occurrence of different species are the character of the stream bed, the amount of vegetation, and especially the quantity and quality of the available food (Hynes 1963, Lillehammer 1974b, 1975, Feminella \& Steward 1986, Ernst \& Steward 1986, Allan et al. 1987, Malmqvist et al. 1991). Factors such as intra- and interspecific relationships influencing on the life cycles and growth of stoneflies were discussed by Malmqvist 
and Sjöström (1989). Stoneflies are also known to be sensitive to certain human impacts such as eutrophication, acidification and stream regulation (e.g. Bagge \& Salmela 1978, Harmanen 1980, Saltveid et al. 1987) and they have been frequently used as indicators of water quality (Persoone \& DePauw 1979).

Inspired by the promising results of Kuusela \& Pulkkinen (1978), who studied the emergence of stoneflies by means of slit traps in the streams of NE Finland, we carried out intensive samplings with similar traps in seven streams of central Finland during the summers 1982-1987. Besides adults, we also collected larvae in the vicinity of the traps. The aim of the study was to compare the occurrence, mean abundance and community structure of stoneflies in streams with differing discharge and somewhat different water quality.

\section{Some characteristics of the streams studied}

According to morphometry and mean flow (MQ) the streams studied were grouped into brooks, small rivers and lake outlet streams. The main parameters used in the comparison of the plecopteran communities in the streams were:

1. Species diversity (total number of species obtained in each stream)
2. Percentage of different species in the total material from each stream

3. Mean abundance of emerging adults/summer found in the traps

4. The ratio shredders/predators, the main functional feeding types of plecopteran larvae.

(cf. Bagge \& Salmela 1978). The brooks (Tuomipuro, Köntysjoki, Keskinen and Autiojoki) are tributaries of the R. Tourujoki emptying into L. Jyväsjärvi in the city of Jyväskylä (Fig. 1). They are characterized by brown and slightly acidic water and variable character of the stream beds (Table 1). In the early 1970's the stream Autiojoki was heavily loaded with sewage (Bagge \& Salmela 1978), but at present the water quality is relatively good.

The River Könkköjoki is a short brown water stream emptying into L. Petäjävesi. It receives acid and iron-rich waste waters from a metal factory which may explain the high colour and acid reaction of the water. In spring, the $\mathrm{pH}$ may fall below 6.0 in the lower reaches of the stream (Vainonen 1988). The River Muuramenjoki (Fig. 1) is a short oligotrophic outlet stream emptying in the L. Päijänne. It has relatively clear water with plenty of rapids and abundance of moss on the rocks.

Siikakoski is a short large oligotrophic outlet stream of L. Konnevesi characterized by clear and neutral water and a mainly sandy and stony bottom with dense stands of Myriophyllum alterniflorum and Potamogeton spp. (Heinonen 1981, Bagge 1987).

Table 1. Some characteristics of the streams studied

\begin{tabular}{|c|c|c|c|c|c|c|}
\hline & $\begin{array}{l}\mathrm{MQ} \\
\mathrm{m}^{3} / \mathrm{s}\end{array}$ & $\mathrm{pH}$ & $\begin{array}{l}\text { Colour } \\
\mathrm{mgPt} / \mathrm{l}\end{array}$ & $\begin{array}{l}\text { Total P } \\
\mu \mathrm{g} / \mathrm{l}\end{array}$ & $\begin{array}{r}\text { Stream } \\
\text { bed }\end{array}$ & Vegetation \\
\hline \multicolumn{7}{|l|}{ Brooks } \\
\hline Tuomipuro & 0.2 & 6.7 & 100 & 22 & mud, silt, stones & + \\
\hline Köntysjoki & 0.3 & 0.6 & 125 & 20 & sand, stones & ++ \\
\hline Keskinen & 0.4 & 6.9 & 100 & 14 & gravel, stones & +++ \\
\hline Autiojoki & 0.6 & 6.7 & 90 & 20 & silt, sand & + \\
\hline \multicolumn{7}{|l|}{ Small river } \\
\hline Könkköjoki & 1.4 & 6.2 & 70 & 16 & sand, stones & ++ \\
\hline \multicolumn{7}{|l|}{ Outlet streams } \\
\hline Muuramenjoki & 3.6 & 6.6 & 45 & 20 & gravel, stones & +++ \\
\hline Siikakoski & 45.0 & 7.2 & 29 & 9 & gravel, stones & ++ \\
\hline
\end{tabular}




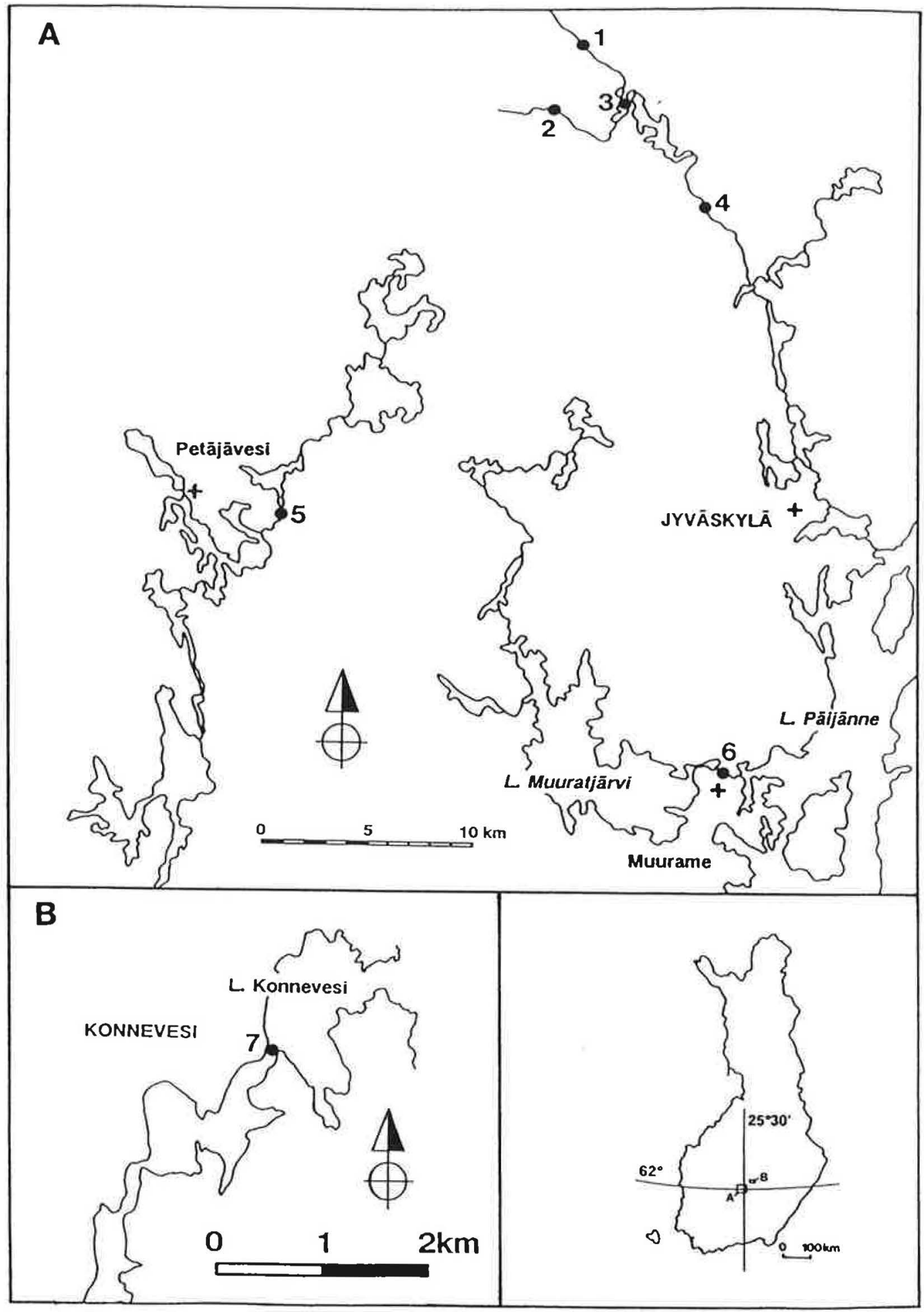

Fig. 1. Location of the streams studied. 1: Tuomipuro, 2: Köntysjoki, 3: Keskinen, 4: Autiojoki, 5: Könkköjoki, 6: Muuramenjoki and 7: the outlet stream Siikakoski. 


\section{Material and methods}

The total material consisted of c. 4500 adults and 2900 larvae which were sampled by means of slit traps or by means of a kick net (mesh size 0.4 or $1.0 \mathrm{~mm}$ ). The scheme of samplings in the different streams is presented in Table 2.

The slit traps (breadth $1 \mathrm{~m}$, height $0.7 \mathrm{~m}$ ) were constructed of two steel plates instead of the tempered hard board used in the original construction by Kuusela \& Pulkkinen 1978. The traps were installed on the stream bank parallel with the water line 1-2 $\mathrm{m}$ from the shoreline and were emptied at intervals of $8-12$ days. The effectiveness of the traps was based on the behaviour of adult stoneflies. After emerging they usually crawl forwards bushes or forest and seek hiding places in the tree canopy. When encountering the traps they more crawl upward on the inner surface of the outer plate (which is installed tightly against the ground) and then fall to a groove where they are killed rapidly by the preservative (diluted ethylene glycol).

\section{Results}

\subsection{Number of species and the composition of plecopteran communities}

A total of 19 species of stoneflies were detected in the streams studied (Table 3). The number of species was highest in small forest brooks
(Köntysjoki 16 species) and lowest in the outlet streams (Siikakoski 9 species).

Dominant species in the brooks were Leuctra hippopus, L. digitata and Nemoura cinerea (Table 3). Occasional species found only in the brooks were Capnia atra, Capnopsis schilleri, Amphinemura standfussi and Nemurella pictetii.

The plecopteran fauna of the R. Könkköjoki was dominated by Leuctra fusca (57\% of all specimens). Other important species in the community were Isoperla spp. and Leuctra digitata.

The moss-covered rapids of the outlet stream Muuramenjoki were dominated by Amphinemura borealis, Isoperla spp. and Nemoura cinerea. Other species occurred only occasionally.

The large outlet of Siikakoski had a poor plecopteran community in which the dominant species were Leuctra fusca and Isoperla obscura. In addition to species listed in Table 3, two larvae of Diura nanseni were found in the stream in autumn 1989.

\subsection{Emergence of adults in the streams}

The continuous sampling by means of slit traps during the most of the flight period made it possible to evaluate the relative abundance of stonefly species in the streams (Table 4). This abundance may be expressed as ind./trap/summer or ind./1 meter shore line, since the breadth of the trap was $1 \mathrm{~m}$.

The highest annual trapping of emerging stoneflies was observed in the streams Könkköjoki

Table 2. Study years, number of traps and catches of stoneflies

\begin{tabular}{llcclr}
\hline Stream & $\begin{array}{l}\text { Adults } \\
\text { Study } \\
\text { year(s) }\end{array}$ & $\begin{array}{l}\text { Number of } \\
\text { traps }\end{array}$ & $\begin{array}{l}\text { Total } \\
\text { catch }\end{array}$ & $\begin{array}{l}\text { Larvae } \\
\text { Study } \\
\text { year(s) }\end{array}$ & $\begin{array}{r}\text { Total } \\
\text { catch }\end{array}$ \\
\hline Tuomipuro & 1982 & 3 & 392 & 1975 & 36 \\
Köntysjoki & 1982,1983 & 2 & 1067 & 1975,1983 & 856 \\
Keskinen & 1982,1983 & 2 & 482 & 1975,1983 & 67 \\
Autiojoki & 1982 & 2 & 147 & 1975,1980 & 28 \\
R.Könkköjoki & 1984 & 5 & 1604 & 1984,1985 & 1390 \\
Muuramenjoki & 1987 & 4 & 681 & 1982,1984 & 448 \\
Siikakoski & 1983 & 5 & 83 & 1983 & 55 \\
& & & 4456 & Sum & 2915 \\
\hline
\end{tabular}


and Köntysjoki where Leuctra spp. were dominating. Relatively high trappings were found also in the streams Muuramenjoki and Keskinen, where Amphinemura borealis was abundant in moss-rich rapids. In the large outlet Siikakoski, the occurrence of larvae was very low, and thus the emergence of stoneflies meagre.

Considerable annual differences in the numbers of emerging adults were observed in the brooks, where the emergence was followed at least during two summers. The differences were most pronounced in the stream Keskinen (Fig. 2, Table 3).

In the brooks as well in the forest river Könkköjoki, the emergence of stoneflies had two clear maxima (Fig. 2 and 3): one in spring and another in late autumn. During the spring, the most abundant species were Leuctra hippopus, Isoperla difformis, Nemoura flexuosa and Amphinemura borealis (in June). In autumn, the catches were dominated by Leuctra digitata and
L. fusca. Some signs of the existence of two maxima are seen also in the emergence of stoneflies in the outlet stream Siikakoski in 1983 (Fig. 4), but the numbers are very low. In the outlet stream Muuramenjoki in 1987, only one peak of emergence was observed in June (Fig. 5), and the autumnal emergence was very weak owing to the exceptionally strong floods which hampered the catching.

\subsection{Occurrence of functional feeding groups of stoneflies in the streams studied}

According to feeding habits, stoneflies are usually grouped into predators (species $1-5$ in Table 3) and shredders (species 6-19 in Table 3). The relation of shredders to predators (basing on the total number of individuals observed in the streams) shows that shredders clearly dominate

Table 3. Percentage of the plecopteran species in the streams studied ( $+=<1 \%$ of total number of ad. + larvae). Symbols: 1) Brooks: Tp =Tuomipuro, $\mathrm{Kj}=$ Köntysjoki, Kk = Keskinen, Aj = Autiojoki; 2) River: Kö = Könkköjoki, 3) Outlet streams: $\mathrm{Mj}=$ Muuramenjoki, Sk = Siikakoski.

\begin{tabular}{|c|c|c|c|c|c|c|c|}
\hline & $\mathrm{Tp}$ & $\mathrm{Kj}$ & $\mathrm{Kk}$ & $\mathrm{Aj}$ & Kö & Mj & Sk \\
\hline Diura bicaudata (Linné) & 4 & + & - & + & + & 4 & 2 \\
\hline Isoperla difformis (Klapálek.) & - & 2 & - & - & 2 & - & \\
\hline I. grammatica (Poda) & + & 2 & 10 & 7 & 1 & 32 & 4 \\
\hline 1. obscura (Zetterstedt) & - & 5 & 3 & 1 & 6 & 7 & 15 \\
\hline $\begin{array}{l}\text { Siphonoperla burmeisteri } \\
\text { (Pictet) }\end{array}$ & - & + & _- & - & + & - & \\
\hline $\begin{array}{l}\text { Taeniopteryx nebulosa (Linné } \\
\text { Amphinemura borealis }\end{array}$ & é) - & 3 & - & - & + & + & 3 \\
\hline (Morton) & 1 & 3 & 32 & 3 & 3 & 47 & 4 \\
\hline A. standfussi (Ris) & - & - & + & + & - & - & \\
\hline A. sulcicollis (Stephens) & + & - & - & + & + & - & \\
\hline Nemoura avicularis Morton & - & 3 & 1 & 3 & 3 & - & \\
\hline N. cinerea (Retzius) & 8 & 3 & 41 & 22 & 2 & 8 & 1 \\
\hline N. flexuosa Aubert & 2 & 3 & 7 & 2 & 2 & + & \\
\hline Nemurella pictetii Klapálek & + & - & + & 1 & - & - & \\
\hline Protonemura meyeri (Pictet) & + & 1 & 1 & - & 1 & - & \\
\hline Capnia atra Morton & - & + & - & - & - & - & \\
\hline Capnopsis schilleri (Rostock) & 1 & 3 & + & 5 & - & - & \\
\hline Leuctra digitata Kempny & 17 & 29 & 2 & 23 & 5 & + & \\
\hline L. fusca (Linné) & 6 & 2 & 3 & 19 & 57 & + & 60 \\
\hline L. hippopus Kempny & 61 & 40 & + & 12 & 3 & + & \\
\hline Unidentified larvae & - & - & - & - & 13 & - & 8 \\
\hline Total catch & 428 & 1923 & 584 & 177 & 2994 & 1129 & 138 \\
\hline
\end{tabular}




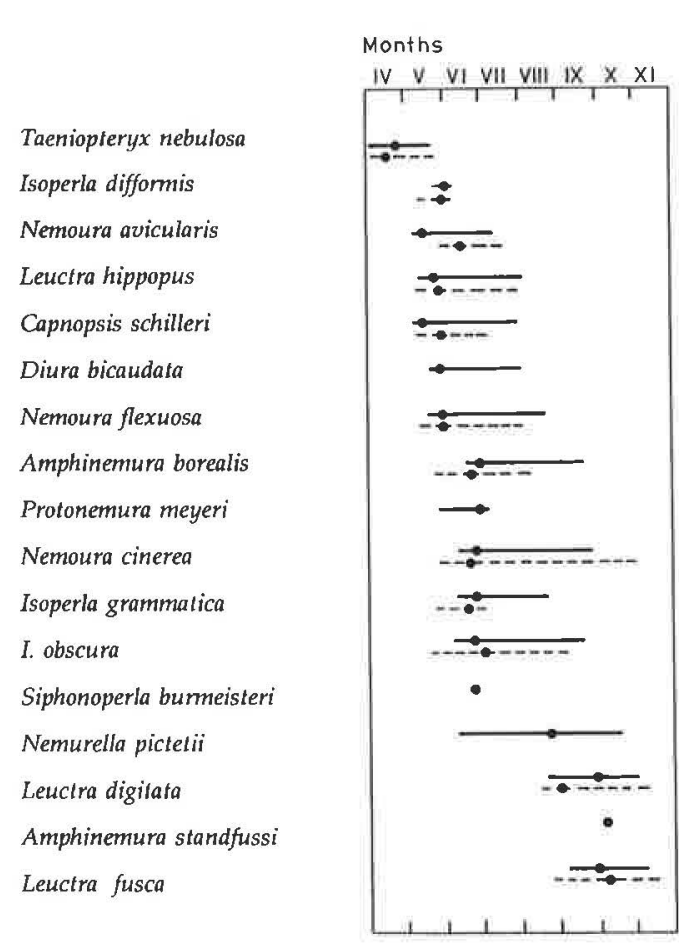

Fig 2. Flight periods of stoneflies in the brooks in 1982 (continuous line), and in 1983 (broken line). Black circle $=$ median date when $50 \%$ of the population had emerged.

in the brooks and in the R. Könkköjoki while the ratio is more even in the outlet streams (Table 5).

\section{Conclusions}

Of the total of 19 species of stoneflies detected in the seven streams, Isoperla difformis, Nemourella pictetii, Capnia atra and Capnopsis schilleri were recorded for the first time in these streams of the province Pohjois-Häme $(T b$.). Faunistically the new finds of Isoperla difformis are interesting since there are only a few earlier records of the species in eastern Fennoscandia (Meinander 1965).

As was reported from Southern Sweden by Malmqvist \& Sjöström (1989), the sexual dimorphism in I. difformis is very prominent in Finland, as well, males being micropterous and thus having restricted ability to spread. Malmqvist \& Sjöström (1989) suggested that $I$. difformis, being found in a rather restricted amplitude of physico-chemical conditions, is constrained by factors like temperature in south Sweden, where it approaches the margins of its distribution. This may be also the explanation for its rarity in Finland. Isoperla grammatica, which is more widely distributed, seems to choose prey of optimal size more readily than does the more synchronously developing 1 . difformis. The former species appears to be a 'specialist' in the most widely accessible food, e.g. chironomids and algae, and for this reason it may exist in a wider range of habitats than $I$. difformis, also in terms of food availability (Malmqvist et al. 1991).

Considerable regional differences were observed in the composition and diversity of the plecopteran communities in the streams studied. The highest diversity of species and highest annual abundance of emerging adults were observed in brooks and small rivers flowing in the forests and fringed by a rich riparian vegetation. In such habitats, the shredders, especially Leuctra spp., were usually dominating. In these types of streams the River Continuum Concept (Vannote et al. 1980) considers coarse particulate organic matter (CPOM) to be an important food source for shredders, but also for generalists. Ernst \& Steward (1986) pointed out that CPOM associations are not limited to shredders but also include predators, and provide an added niche dimension for these groups and is important in stream community structure and function.

Other habitats with a rich plecopteran fauna were rapids with a rich moss-cover, where Amphinemura borealis especially occurred abundantly. The large outlet of Siikakoski (MQ $45 \mathrm{~m}^{3}$ ), which is dominated by filter feeders like blackflies and hydropsychids, had a poor plecopteran fauna (9 species) and an annual emergence of only 17 ind./trap. Another peculiar character of the plecopteran fauna of the outlet streams was its high proportion of predators (especially Isoperla spp.) compared to that of shredders. This finding is in concordance with the observations of Kuusela (1984), who found that in the brook Rytipuro (Kuusamo) the percentage of predatory Perloidea was only $1 \%$ of the total number of emerging individuals, while in the large $\mathrm{R}$. Oulankajoki their proportion was $17.6 \%$. The scarcity of shredders in the outlet streams may depend on the small amount of leaf litter and other coarse particulated organic 
material present in the lake outlets (cf. Hynes 1963, Lillehammer 1974b, 1975). Malmqvist and Otto (1987) showed that I. grammatica did quite well on substrates with a low stability, where blackflies were abundant. An association between the distribution of $I$. grammatica and blackfly larvae was also demonstrated by Malmqvist and Sjöström (1984).

In the brooks as well as in the forest river Könkköjoki, the emergence of stoneflies had two maxima: one in spring and early summer and another in autumn. Vernal species in the material were Taeniopteryx nebulosa, Isoperla difformis, Nemoura avicularis, N. flexuosa and Leuctra hippopus. Dominant species in the autumnal catches were Leuctra digitata and $L$. fusca. This is in concordance with the observations of Meinander (1965). There is about one month delay in the timing of life cycles from southern Finland to northern Finland (Kuusela 1984), mainly caused by the temperature differences. The timing of the life cycles of the congeneric

Table 4. Relative abundance (ind./trap/summer) of emerging stoneflies in the streams studied $(+=<1 \mathrm{ind}$./trap/ summer). Locality symbols as in Table 3.

\begin{tabular}{|c|c|c|c|c|c|c|c|c|c|}
\hline & $T p$ & $\mathrm{Kj}$ & $\mathrm{Kj}$ & Kk & $\mathrm{Kk}$ & $\mathrm{Aj}$ & Kö & Mj & Sk \\
\hline Study year & 1982 & 1982 & 1983 & 1982 & 1983 & 1982 & 1984 & 1987 & 1983 \\
\hline Diura bicaudata & 1 & - & - & - & - & - & + & - & + \\
\hline Isoperla difformis & - & 1 & 12 & - & - & - & 11 & - & _ \\
\hline 1. grammatica & - & 1 & - & 14 & 3 & 1 & 4 & 58 & 1 \\
\hline $\begin{array}{l}\text { 1. obscura } \\
\text { Siphonoperla }\end{array}$ & - & 1 & 3 & 5 & 3 & 1 & 4 & 11 & 4 \\
\hline burmeisteri & - & 1 & - & - & - & - & 2 & - & - \\
\hline Taeniopteryx nebulosa & - & 8 & 4 & - & - & - & - & + & + \\
\hline Amphinemura borealis & 1 & 6 & 17 & 60 & 21 & 3 & 2 & 97 & 1 \\
\hline A. standfussi & - & - & - & + & - & - & - & - & - \\
\hline Nemoura avicularis & - & 19 & 3 & 1 & 1 & 3 & + & - & - \\
\hline N. cinerea & 8 & 9 & 6 & 60 & 41 & 19 & 4 & 4 & + \\
\hline N. flexuosa & 1 & 10 & 10 & 18 & 2 & 3 & 2 & - & - \\
\hline Nemurella pictetii & + & - & - & 1 & - & 1 & - & - & - \\
\hline Protonemura meyeri & 1 & 2 & - & - & - & - & 1 & - & - \\
\hline Capnopsis schilleri & 1 & 26 & 5 & + & - & 3 & - & - & - \\
\hline Leuctra digitata & 21 & 31 & 61 & 4 & 2 & 13 & 20 & + & - \\
\hline L. fusca & 9 & 11 & 8 & - & 8 & 17 & 262 & + & 10 \\
\hline L. hippopus & 85 & 131 & 149 & - & - & 11 & 7 & + & - \\
\hline Total mean: & 128 & 257 & 278 & 163 & 81 & 75 & 321 & 171 & 17 \\
\hline
\end{tabular}

Table 5. Relation of shredders (Euholognatha) to predators. (Systellognatha) in the streams studied.

\begin{tabular}{lrrr}
\hline $\begin{array}{l}\text { Small forest } \\
\text { streams }\end{array}$ & $\begin{array}{r}\text { Shredders: } \\
\text { predators }\end{array}$ & $\begin{array}{r}\text { Larger } \\
\text { outlets }\end{array}$ & $\begin{array}{r}\text { Shredders: } \\
\text { predators }\end{array}$ \\
\hline $\begin{array}{l}\text { Tuomipuro } \\
\text { Köntysjoki }\end{array}$ & $24: 1$ & Muuramenjoki & $1.2: 1$ \\
Autiojoki & $10: 1$ & Siikakoski & $2.5: 1$ \\
Könkköjoki & $11: 1$ & & \\
Keskinen & $7: 1$ & & \\
\hline
\end{tabular}


Isoperla difformis

Protonemura meyeri

Diura bicaudata

Nemoura cinerea

$N$. avicularis

N. flexuosa

Leuctra hippopus

Amphinemura borealis

Isoperla grammatica

I. obscura

Siphonoperla burmeisteri

Leuctra fusca

Total catch Ind./trap/day
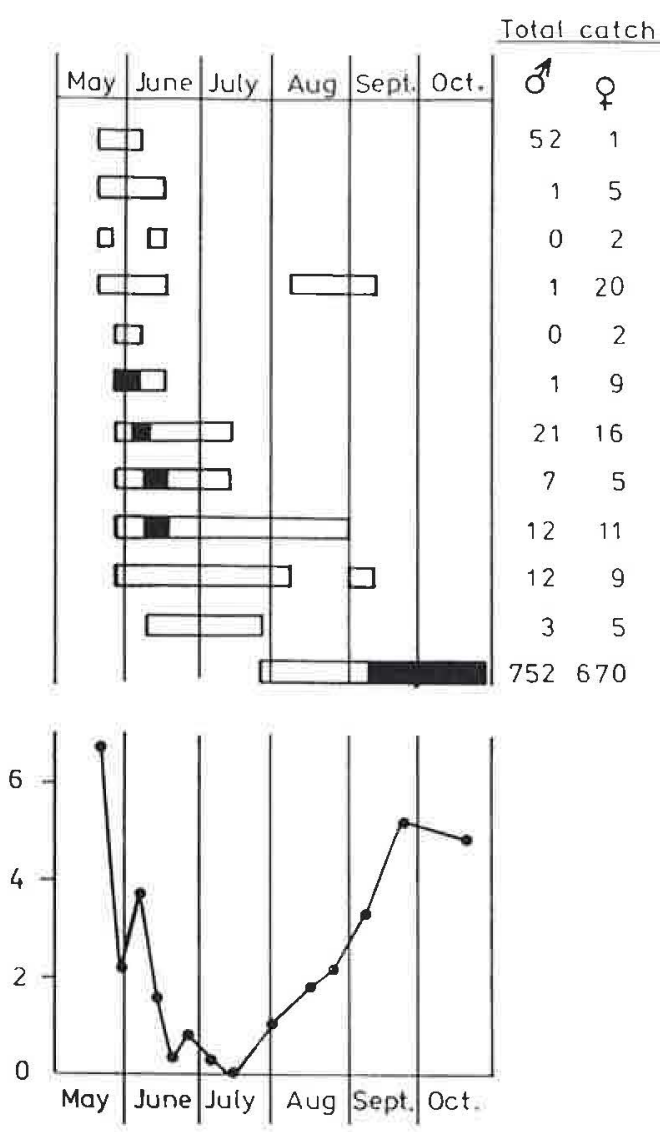

Fig 3. Total emergence of adult stoneflies in the River Könkköjoki (catch of four slit traps, May 18October 28. 1984). Solid black = maximum emergence.

Diura bicaudata

Isoperla obscura

I. grammatica

Amphinemura borealis

Nemoura cinerea

Leuctra fusca

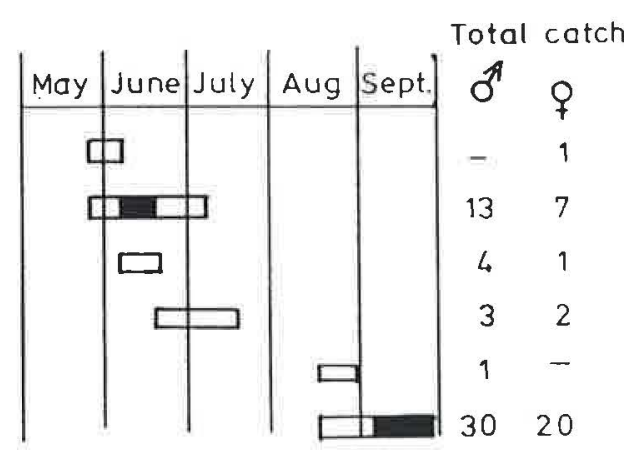

Total catch Ind./trap/day

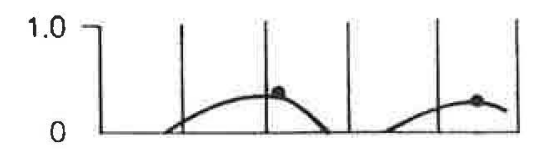

Fig. 4. Total emergence of adult stoneflies in the outlet stream Siikakoski (catch of five slit traps, May 25- September 28. 1983). Solid black $=$ maximum emergence. 
Leuctra hippopus

Isoperla obscura

I. grammatica

Amphinemura borealis

Nemoura cinerea

Leuctra digitata

L. fusca

Total catch Ind / trap/day
Fig 5. Total emergence of adult stoneflies in the outlet stream Muuramenjoki (catch of four slit traps, May 15- November 11. 1987). Solid black = maximum emergence.

species differed in many cases. Emergence of Isoperla difformis, Nemoura avicularis and Leuctra hippopus took place in early spring, and was highly synchronous, while in Isoperla grammatica, I. obscura, Nemoura cinerea and Leuctra fusca, the emergence extended over several months. Feminella \& Stewart (1986) suggested that the likehood of competition among the congeneric stonefly species is minimized by the timing of their life cycles.

The slit trap method used in the catching of adult stoneflies worked well during most of the sampling time. In early spring and in late autumn the snow covered the traps, and this may have affected the trapping of early and late emerging species such as Taeniopteryx nebulosa and Leuctra fusca. Other problems in the catching were caused by heavy floods, especially in 1987, when the flow in the streams of central Finland was almost doubled. Despite the difficulties mentioned, the slit trap is quite usable, especially in faunistic collecting.

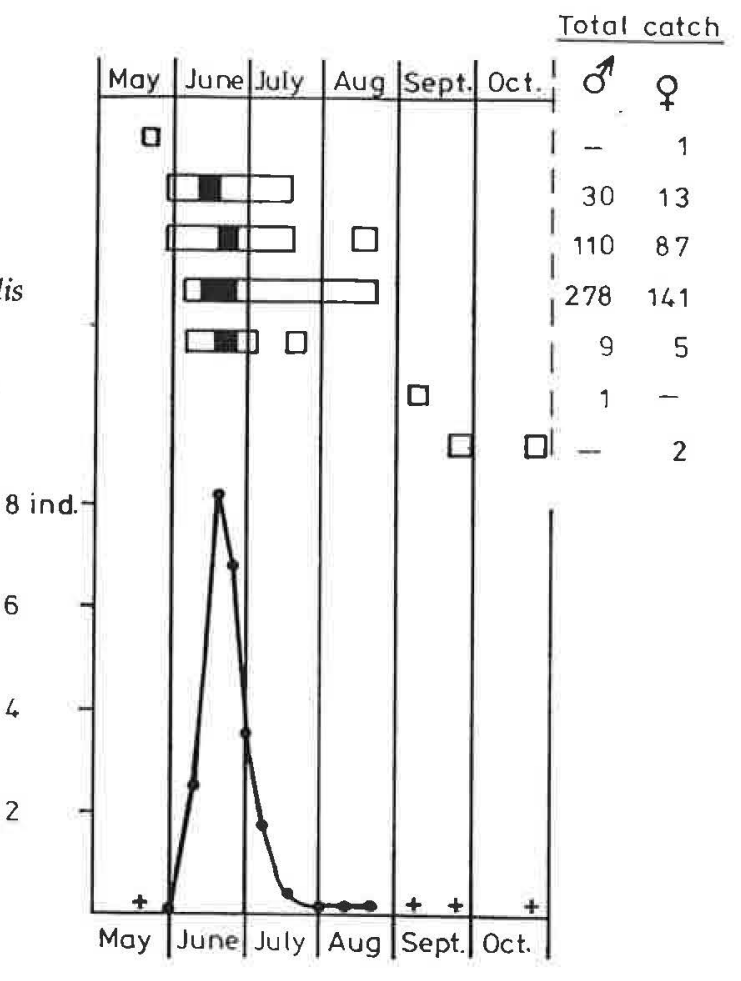

Acknowledgements. We wish to thank the following hydrobiologists who have helped us in the field work: M.Sc. Jussi Kirjasniemi, M.Sc. Markku Laitinen, M.Sc. Anneli Vainonen and Lic.phil. Pentti Valkeajärvi. M.Sc. Veli-Matti Salmela constructed the slit traps.

\section{References}

Allan, D. J., Flecker, A. S. and McClintock, N. L. 1987: Prey size selection by carnivorous stoneflies. Limnol. Oceanogr. 32:864-872.

Bagge, P. 1987: Emergence and distribution of Hydroptilidae in the littoral and outlet biocoenoses of Lake Konnevesi (Central Finland). - In Bournaud, M. \& Tachet, H. (eds): Proc. 5th Int. Symp, on Trichoptera. Dr. W. Junk Publ. 1987 pp. 337-341.

Bagge, P. \& Salmela, V-M. 1978: The macrobenthos of the River Tourujoki and its tributaries (Central Finland). 1. Plecoptera, Ephemeroptera and Trichoptera. — Notulae Entomol. 58:159-168.

Brinck, P. 1952: Bäcksländor, Plecoptera. - Svensk Insektfauna. Stockholm 1952:1-126.

Ernst, M. R. and Steward, W. 1986: Microdistribution of eight stonefly species (Plecoptera) in relation to organic 
matter in an Ozark Foothills Stream. - Aquatic Insects 8:237-254.

Feminella, J. W. and Steward, K. W. 1986: Diet and predation by three leaf-associated stoneflies (Plecoptera) in an Arkansas mountain stream. - Freshwater Biology 16:521-538.

Harmanen, M. 1980: Der Einfluss saurer Gewässer auf den Bestand der Ephemeriden-und Plecopteren fauna. — Gewässer und Abwässer 66:130-136.

Heinonen, P. 1984: Early warning of eutrophication in rivers by analysis of periphyton chlorophyll a. - In Pascoe D. \& Edwards R. W. (eds.): Freshwater Biological Monitoring. Pergamon Press 1984, pp. 4552.

Hynes, H. B. N. 1963: Imported organic matter and secondary productivity in streams. - Proc. Int. Congr. Zool. 16:324-329.

Kuusela, K. 1984: Emergence of Plecoptera in two lotic habitats in the Oulanka National Park, northeastern Finland. - Annls Limnol. 20 (1-2):63-68.

Kuusela, K. \& Pulkkinen, H. 1978: A simple trap for collecting newly emerged stoneflies (Plecoptera). Oikos 31:323-325.

Lillehammer, A. 1974: Norwegian stoneflies II. Distribution and relationship to the environment. - Norsk Entomol. Tidskr. 21:195-250.

Lillehammer, A. 1975: Norwegian stoneflies III. Field studies on ecological factors influencing distribution. Norw. J. Entomol. 22:71-80.

Malmqvist, B. \& Otto C.: 1987: The influence of substrate stability on the composition of streams benthos: An experimental study. - Oikos 48:33-38.
Malmqvist, B. \& P. Sjöström 1984: The microdistribution of some lotic predators in relation to their prey and to abiotic factors. - Freshwater Biology 14:649-656.

Malmqvist, B. and Sjöström, P. 1989: The life cycle and growth of Isoperla grammatica and I. difformis (Plecoptera) in southermost Sweden: intra- and interspecific considerations. - Hydrobiologia 175:97-108.

Malmqvist, B., Sjöström, P. and Frick, K. 1991: The diet of two species of Isoperla (Plecoptera: Perlodidae) in relation to season, site, and sympatry. - Hydrobiologia 213:191-203.

Meinander, M. 1965: List of the Plecoptera of Eastern Fennoscandia. - Fauna Fennica 19:1-38.

Persoone, G \& DePauw, N. 1979: Systems of biological indicators for water quality assessment. - In Ravera, O. (ed.): Biological Aspects of Freshwater Pollution, pp. 39-75.

Saltveid, S. J., Brittain, J. E. \& Lillehammer, A. 1987: Stoneflies and river regulation - review. - In Craig, J. F. \& Kemper, J. B. (eds): Regulated rivers. Plenum Publ. Corporation 1987, pp. 117-129.

Standford, J. A. \& Ward, J. V. 1983: Insect species diversity as a function of environmental variability and disturbance in stream systems. - In Barnes, J. R. \& Minshall, G. W. (eds): Stream Ecology. Plenum Press 1983, pp. 265-278.

Vainonen, A. 1988: [The drift and diumal activity of zoobenthos in some streams of Petäjävesi commune in summer 1984]. - Unpublished thesis, Department of Biology, University of Jyväskylä.

Vannote, R. L., Minshall G. W., Cummins K. W., Sedell, J. R. and Cushing, C. E. 1980: The river continuum concept. - Can. J. Fish. Aquat. Sci. 37:130-137. 